\title{
PULMONARY EMBOLISM IN YOUNG AGE
}

\author{
Kulminskaya V., Makienko N., Shmidt O., Ivleva O.
}

Introduction. One of the risk factors for pulmonary embolism is age \&gt; 40 years. Lately, more and more cases of thromboembolism occur at a young age, that requires special attention in diagnosis and treatment.

Objectives. The purpose of this article was to analyze the clinical case of thromboembolism at a young age.

Material and methods. Our patient B., 33- year-old male was urgently hospitalized with the chest pain when breathing in, shortness of breath, blood-streaked sputum cough and body temperature up to $37-38.5^{\circ} \mathrm{C} .17 .12 .18$ the bone immobilization of the right fibula due to a fracture was performed. 30.12.18 - the patient felt compressive pain in the right side of the chest, shortness of breath, blood-streaked sputum cough. An ambulance was called, but the patient was not hospitalized. Since 31.12.2018 till 05.01.2019 - body temperature rose to $38^{\circ} \mathrm{C}$. 06.01 .19 - a recurrence of initial symptoms. 07.01.19 - the chest pain intensified, patient was transported by ambulance to a hospital. During the examination: vesicular breathing, weakened in the lower sections, mostly on the right, respiratory rate $-20 / \mathrm{min}$, heart rate 100 beats/min, blood pressure 120/70 mm Hg. The main diagnosis: thromboembolism of the lobar arteries of the right lung. Class I, very low risk (43 points by PESI scale - Pulmonary Embolism Severity Index, 5 points by the Padua prediction score).

Complication: right-sided inferior infarction-pneumonia. Concomitant diagnosis: fracture of the right fibula. Recommended treatment: rivaroxaban $12 \mathrm{mg}$; eplerenone $50 \mathrm{mg}$, ceftriaxone $1 \mathrm{~g}$ bid intravenous injection (IV), levofloxacin $500 \mathrm{mg} \mathrm{IV}$, oxygen therapy.

Results. Laboratory and instrumental studies were carried out. Laboratory tests revealed an increased in leukocytes, erythrocyte sedimentation rate, ALT, troponin I. ECG: right axis deviation. Computed tomography (CT) of the chest: CT signs of thromboembolism of the arteries of the right lung, right-sided inferior infarction-pneumonia, changes are more typical for an inflammatory process in the initial stage. Ultrasound examination of the abdominal organs and kidneys: diffuse changes of the liver parenchyma, traces of fluid in the right pleural cavity.

Conclusions. Prolonged immobilization in young patients can be only one risk factor for the formation of pulmonary embolism. In order to predict possible complications in patients with pulmonary thromboembolism, it is necessary to take into account the initial state of the patient and associated diseases in each case.

KEY WORDS: pulmonary embolism, young age, complications

\section{INFORMATION ABOUT AUTHORS}

Kulminska Vladislava Y., student of V. N. Karazin Kharkiv National University, school of medicine, 6, Svobody sq., Kharkiv, Ukraine, 61022, e-mail: kulminskayavl@ gmail.com, ORCID ID: https://orcid.org/0000-0002-5389-2060

Makiienko Nataliia V., MD, PhD, Associate professor of Department of Internal Medicine, V. N. Karazin Kharkiv National University, 6, Svobody sq., Kharkiv, 61022, Ukraine, e-mail: n.makienko@karazin.ua,

ORCID ID: https://orcid.org/0000-0003-2017-350X

Shmidt Olena Y., MD of functional diagnostic at Kharkiv railway clinical hospital No.1 of the branch «Center of healthcare» of Joint stock company «Ukrainian Railway», Assistant of Department of Propaedeutics of Internal Medicine and Physical Rehabilitation, V. N. Karazin Kharkiv National University, 6, Svobody Sq., Kharkiv, 61022, Ukraine, e-mail: shmidt05alena@gmail.com, ORCID ID: http://orcid.org/0000-0001-7997-362X

Ivleva Olga A., MD of cardiology department No.1, Kharkiv railway clinical hospital №1 of the branch «Center of healthcare» of Joint Stock Company «Ukrainian Railways», Kharkiv, Ukraine, 61103

\section{INTRODUCTION}

Pulmonary embolism (PE) in the practice of a cardiologist remains a disease that requires timely diagnosis and treatment to prevent patients' disability and mortality [1].

The approximate frequency of pulmonary embolism in Ukraine is 120-130 thousand cases per year [1] and tends to increase [2]. It is known that the incidence of pulmonary embolism in young people is significantly lower than in older $[3,4]$, while mortality at the age of 20-39 years is higher compared with other age groups $[4,5]$. According to sources
[4], in most cases the cause of pulmonary embolism in a cohort of young patients is not possible to establish. Some patients are asymptomatic or clinical signs are nonspecific due to the polymorphism of developing syndromes [6], which often leads to accidental or late diagnosis of the pathology.

In clinical practice, there are some difficulties in diagnosing PE in young people. This is not only due to non-specific clinical picture, requiring a differential approach, but also to the lack of informative and accessible diagnostic method and recommendations for the 
primary prevention of the development of this pathology [7].

\section{CLINICAL CASE}

33-year-old, male, a resident of the region.

\section{COMPLAINTS}

Patient B., hospitalized in emergency order with complaints of pain in the right half of the chest when breathing in, the pain intensified in the evening; cough in the morning, with expectration of blood streaks; body tempe-rature rise up to $37-38.5^{\circ} \mathrm{C}$ in the evening; shortness of breath during normal physical exertion.

\section{ANAMNESIS MORBI}

Considers himself ill since 17.12.18, when after fracture of the right fibula the bone immobilization was performed, bed rest was recommended. 30.12.18 - being at home, the patient felt compressive pain in right side of the chest, shortness of breath, cough with expectoration of viscous mucus with blood streaks. An ambulance was called, blood pressure (BP) was measured and ECG was made. The patient was not hospitalized.

From 31.12.2018 till 05.01.2019 there was an increase in body temperature to $38^{\circ} \mathrm{C}$. 06.01.19 - the patient had a recurrence of chest pain (with increased at night), shortness of breath, expectoration of viscous mucus with blood streaks. 07.01.19 - the chest pain intensified, and therefore patient called ambulance and was hospitalized in Kharkiv hospital for railways № 1 of the branch «Health Center» Public Joint Stock Company «Ukrainian Railways», cardiology department 1 for examination, verification of diagnosis and treatment.

\section{ANAMNESIS VITAE}

Patient did not suffer from intestinal infections, viral hepatitis, malaria, helminthic invasions, diabetes, tuberculosis or allergic reaction to medicines. But he had an allergic reaction to ambrosia (lacrimation and runny nose during flowering). Family history had no significant information. Risk factors: immobilization due to fracture of the right fibula 17.12.18.

\section{OBJECTIVE STATUS}

Consciousness is clear, pale pink skin, peripheral lymph nodes are not enlarged. The body mass index is $24.9 \mathrm{~kg} / \mathrm{m}^{2}$. The lobes of the thyroid gland are not clearly defined. The isthmus of the thyroid gland is palpable, painless, not welded to other tissues. Muscularskeletal system: a plaster cast on the right leg. Percussion: over most of the lungs area a resonant sound was revealed, but in the lower sections (mostly on the right side) there was a slight dullness of the pulmonary sound. Auscultation: vesicular breathing, weakened in the lower sections, mostly on the right. Respiratory rate $-20 / \mathrm{min}$. The borders of relative cardiac dullness were not shifted. Heart auscultation: rhythmic heart activity, heart sounds - there was accentuated $2^{\text {nd }}$ heart sound in the second intercostal space on the left. Heart rate $=$ pulse $=100$ beats $/ \mathrm{min}$. Blood pressure $120 / 70 \mathrm{~mm} \mathrm{Hg}$ on the right and left hands. Abdomen of normal size, soft and painless on palpation, the lower border of the liver at the edge of the costal arch, painless. Physiological responses are within normal. Costovertebral angle tenderness is negative on both sides. Pitting oedema on the left lower extremity is absent, the right - in a plaster cast to the knee.

\section{RESULTS OF INVESTIGATIONS}

Laboratory and instrumental studies were carried out.

A clinical analysis of blood revealed an increase in leukocytes of $10.8 \times 10^{9} \mathrm{~g} / 1(\mathrm{~N} 4.0$ $\left.9.0 \times 10^{9} \mathrm{~g} / \mathrm{l}\right)$, Erythrocyte sedimentation rate of $23 \mathrm{~mm} / \mathrm{min}$ (up to $20 \mathrm{~mm} / \mathrm{min}$ ).

Biochemical blood tests revealed an increased level of ALT up to 42.6 units / 1 (N $<31$ units/l) and troponin I up to $34.5 \mathrm{ng} / 1$ (N $\leq 25 \mathrm{ng} / \mathrm{l})$.

Echocardiography (ECHO-KG), conclusion: the heart chambers are not dilated, the myocardium is not thickened, no areas of akinesia have been revealed. Indicators of myocardial contratility and pumping function of the left ventricle saved (left ventricular ejection fraction $76 \%)$.

Computed tomography (CT) of the chest, conclusion (fig. 1,2): there are CT signs of thromboembolism of the arteries of the right lung, right-sided inferior infarction-pneumonia. Changes in the lower lobe of the left lung are more typical for an inflammatory process in the initial stage. 


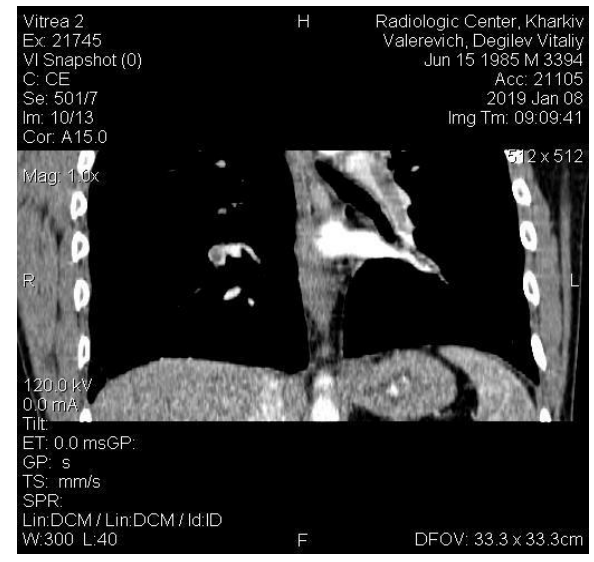

Fig. 1.

Ultrasound examination (ultrasound) of the abdominal organs and kidneys: there are diffuse changes of the liver parenchyma, traces of fluid in the right pleural cavity. The inferior vena cava is not dilated.

ECG: there is shift of the electrical axis to the right.

The main diagnosis: thromboembolism of the lobar arteries of the right lung. Class I, very low risk (43 points by PESI scale - Pulmonary Embolism Severity Index, 5 points by the Padua prediction score).

Complication: right-sided inferior infarctionpneumonia. fibula.

Concomitant diagnosis: fracture of the right

\section{RECOMMENDED DRUG THERAPY}

Antithrombotic drugs. ATH code V01FF01 - rivaroxaban $12 \mathrm{mg}$ once a day for long-time use; potassium-sparing diuretics, aldosterone antagonists, ATX code C03D A04 - eplerenone $50 \mathrm{mg}$ once a day; antibacterials for systemic use, other beta-lactam antibiotics, thirdgeneration cephalosporins, code ATXJ01DD04 - ceftriaxone $1 \mathrm{~g}$ twice a day, intravenously, for 7 days; quinolone antibacterial drugs, fluoroquinolones, ATX code J01MA12 levofloxacin $500 \mathrm{mg}$ once a day, intravenously for 7 days; oxygen therapy for 7 days.

Additionally, it was recommended the patient to verify the pathogenetic cause of pulmonary embolism: to exclude the antiphospholipid syndrome with the determination of antiphospholipid antibodies (aFL), associated with autoimmune thrombotic vasculopathy.

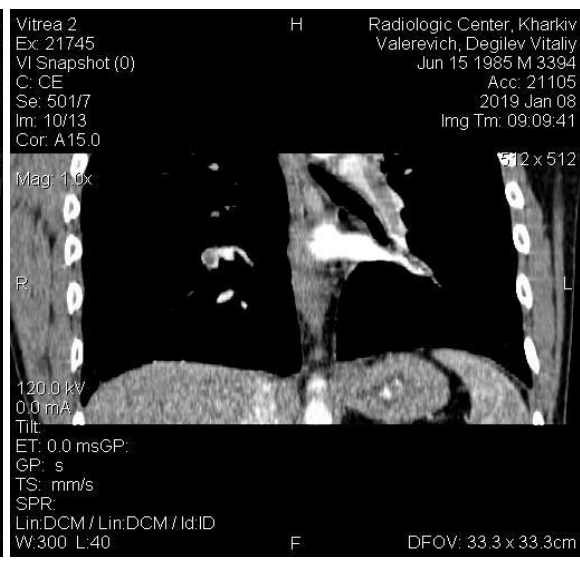

Fig. 2.

\section{DISCUSSION}

Pulmonary embolism remains a poorly explored problem in young patients. This clinical case confirms that the development of pulmonary embolism is possible in young people as often as in patients of middle or older age $[5,9]$.

Considering the aetiology of pulmonary embolism, it is impossible to ignore the risk factors (patient age, immobilization for more than 3 days, bone fractures and others) that form the clinical picture, the progression and complications of the disease [1.3-6].

Clinical manifestation of pulmonary embolism in any age is determined by the degree of obstruction of pulmonary arteries. According to $[1,8,10]$ pulmonary embolism may be accompanied by an acute debut (sudden onset, chest pain, shortness of breath, a drop in blood pressure, signs of an acute pulmonary hypertension), subacute (progressive respiratory and right ventricular failure, signs of infarction pneumonia, hemoptysis) and recurrent (repeated episodes of dyspnoea, unmotivated syncope, collapse, signs of pneumonia, pleurisy, fever, the appearance or progression of heart failure, resistant to therapy, the appearance and progression of signs of subacute or chronic pulmonary heart disease; danger of death due to massive pulmonary embolism).

Patient complaints, risk factors, the «severity» of the clinical picture require, regardless of age, a timely diagnostic approach, as well as the appointment of therapy according to the recommendations $[10,11]$. The predisposition of young people to the antiphospholipid syndrome [3, 5] should be taken into account and requires a detailed and 
thorough examination in order to prevent complications.

According to [11], antiphospholipid syndrome is an acquired thrombophilic disease when autoantibodies to phospholipid determinants of cell membranes or phospholipid-binding proteins of the blood are produced. Consequently, associated with AFL clinical manifestations can range from asymptomatic carrier state to life-threatening manifestations associated with the size, number, and type of occluded vessels.

To predict possible complications in patients with pulmonary embolism in each individual case it is necessary to take into account the initial state of the patient and comorbidities [2, 4, 10, 11].

\section{CONCLUSION}

The clinical case illustrates that young patients can be classified as risk group with the potential development of pulmonary embolism with certain provoking factors, especially with prolonged immobilization due to a fracture of the bones. The above may be the leading cause of disease progression and the development of complications.

Treatment of young patients with pulmonary embolism is carried out in accordance with recommendations for the management of patients with venous embolism, taking into account all risk factors.

\section{REFERENCES}

1. Пархоменко О.М. Тромбоемболія легеневої артерії / Лутай Я.М. // Настанова з кардіології, за ред. В.М. Коваленка. - К.: МОРІОН, 2009. - С. 818-856.

2. Фесенко О.В. Анализ летальных исходов при тромбоэмболии легочной артерии у лиц молодого возраста / Синопальников А.И., Глечиков А.В. // Терапевтический архив (архив до 2018 г.). - 2013. - № 85 (3) - C. 44-50.

3. Hosna S.A. Acute Pulmonary Embolism in a Young Patient with Deep Vein Thrombosis / Chaudhary M, Haque M.A. // International Journal of Radiology and Radiation Therapy. - 2017.- V.4, №6. - P. 1-3.

4. Chenaghlou M. Risk Factors and Prevention of Pulmonary Embolism in Young Adults / M. Chenaghlou, R. Parizad, M. Asghari Jafarabadi. // Crescent Journal of Medical and Biological Sciences. - 2017. - № 1. - P. 7-12.

5. Mongan J. Age and sexdependent trends in pulmonary embolism testing and derivation of a clinical decision rule for young patients / Kline J, Smith-Bindman R. // Emergency Medicine Journal. - 2015. № 32 - Р. 840-845.

6. Ячник А.І. Тромбоемболія легеневої артерії: варіанти перебігу, гемодинамічні ознаки та особливості тромбоутворення / Шниркова О.В., Ячник В.А., Студнікова В.В. // Український пульмонологічний журнал. - 2016. - № 1. - С. 23-28.

7. Stavros V. Konstantinides. Management of Pulmonary Embolism / Stefano Barco, Mareike Lankeit, Guy Meyer // Journal of the American College of Cardiology. - 2016. - № 8. - P. 976-990.

8. Рекомендації Європейського товариства кардіологів щодо ведення пацієнтів з ТЕЛА (2014), частина 1. // Серце і судини. - 2014. - № 4. - С. 7-14.

9. Рекомендації Європейського товариства кардіологів щодо ведення пацієнтів 3 ТЕЛА (2014), частина 2. // Серце і судини. - 2015. № 1. - С. 7-14.

10. Sakuma M. Pulmonary embolism is an important cause of death in young adults / Nakamura M, Takahashi T // Circulation Journal. - 2007. - № 71. - P. 1765 - 1770.

11. Решетняк Т. М. Антифосфолипидный синдром: диагностика и клинические проявления (лекция). // Научно-практическая ревматология. - 2014. - № 52(1). - С. 56-71.

\section{REFERENCES}

1. Parhomenko O.M. Tromboemboliya legenevoyi arteriyi / Lutaj Ya.M. // Nastanova z kardiologiyi, za red. V.M. Kovalenka. - K.: MORION, 2009. - S. 818-856. (in Ukrainian)

2. Fesenko O.V. Analiz letalnyh ishodov pri tromboembolii legochnoj arterii u lic molodogo vozrasta / Sinopalnikov A.I., Glechikov A. V. // Terapevticheskij arhiv (arhiv do 2018 g.). - 2013. - № 85 (3) S. 44-50. (in Russian)

3. Hosna S.A. Acute Pulmonary Embolism in a Young Patient with Deep Vein Thrombosis / Chaudhary M, Haque M.A. // International Journal of Radiology and Radiation Therapy. - 2017.- V.4, № 6. - P. 1-3.

4. Chenaghlou M. Risk Factors and Prevention of Pulmonary Embolism in Young Adults / M. Chenaghlou, R. Parizad, M. Asghari Jafarabadi. // Crescent Journal of Medical and Biological Sciences. - 2017. - № 1. - P. 7-12. 
5. Mongan J. Age and sexdependent trends in pulmonary embolism testing and derivation of a clinical decision rule for young patients / Kline J, Smith-Bindman R. // Emergency Medicine Journal. - 2015. № 32 - P. 840-845.

6. Yachnik A.I. Tromboemboliya legenevoyi arteriyi: varianti perebigu, gemodinamichni oznaki ta osoblivosti tromboutvorennya / Shnirkova O.V., Yachnik V.A., Studnikova V.V. // Ukrayinskij pulmonologichnij zhurnal. - 2016. - № 1. - S. 23-28. (in Ukrainian)

7. Stavros V. Konstantinides. Management of Pulmonary Embolism / Stefano Barco, Mareike Lankeit, Guy Meyer // Journal of the American College of Cardiology. - 2016. - № 8. - P. 976-990.

8. Rekomendaciyi Yevropejskogo tovaristva kardiologiv shodo vedennya paciyentiv z TELA (2014), chastina 1. // Serce i sudini. - 2014. № 4. - S. 7-14. (in Ukrainian)

9. Rekomendaciyi Yevropejskogo tovaristva kardiologiv shodo vedennya paciyentiv z TELA (2014), chastina 2. // Serce i sudini. - 2015. № 1. - S. 7-14. (in Ukrainian)

10. Sakuma M. Pulmonary embolism is an important cause of death in young adults / Nakamura M, Takahashi T // Circulation Journal. - 2007. - № 71. - P. 1765 - 1770.

11. Reshetnyak T.M. Antifosfolipidnyiy sindrom: diagnostika i klinicheskie proyavleniya (lektsiya). // Nauchno-prakticheskaya revmatologiya. - 2014. - № 52(1). - S. 56-71. (in Russian)

\title{
ТРОМБОЕМБОЛІЯ ЛЕГЕНЕВОЇ АРТЕРїї В МОЛОДОМУ ВІЩІ
}

\author{
Кульмінська В. Ю., Макієнко Н. В., Шмідт О. Ю., Івлева О. О.
}

Вступ. Одним з факторів ризику розвитку тромбоемболії легеневої артерії є вік \&gt; 40 років. Останнім часом зустрічається все більше випадків розвитку тромбоемболії в молодому віці, що вимагає особливої уваги в діагностиці та лікуванні.

Мета. Метою даної статті був аналіз клінічного випадку тромбоемболії в молодому віці.

Матеріал і методи. Наш пацієнт Б., 33 роки, був невідкладно госпіталізований з болем у грудях при вдиху, задишкою, кашлем з мокротою з прожилками крові і підвищенням температури тіла до 37-38,5 ${ }^{\circ} \mathrm{C}$. 17.12.18 іммобілізація правої малогомілкової кістки. 30.12 .18 р з\&\#39;явився стискачийє біль в правій половині грудної клітини, задишка, кашель 3 мокротою 3 прожилками крові. Була викликана бригада швидкої допомоги, але пацієнт не був госпіталізований. 3 31.12.2008 р по 01.05.2009 р - температура тіла підвищилася до $38^{\circ} \mathrm{C}$. 01.06.19 рецидив початкових симптомів. 01.07.19 - біль в грудях посилився, пацієнт був доставлений бригадою швидкої допомоги в лікарню. При обстеженні: дихання везикулярне, ослаблене в нижніх відділах, переважно справа, частота дихання - 20 / хв, частота серцевих скорочень 100 уд / хв, артеріальний тиск 120/70 мм рт. Основний діагноз: тромбоемболія дольових артерій правої легені. Клас I, дуже низький ризик (43 бали за шкалою PESI індекс тяжкості тромбоемболії легеневої артерії, 5 балів за шкалою прогнозу Падуї). Ускладнення: правобічна нижньодолева інфаркт-пневмонія. Супутній діагноз: перелом правої малогомілкової кістки. Рекомендоване лікування: ривароксабан 12 мг; еплеренон 50 мг, цефтриаксон 1 г внутрішньовенно в / в (в / в), левофлоксацин 500 мг в / в, киснева терапія.

Результати. Проведено лабораторні та інструментальні дослідження. Лабораторні тести показали збільшення кількості лейкоцитів, швидкості осідання еритроцитів, АЛТ, тропоніну І. ЕКГ: відхилення осі вправо. Комп\&\#39;ютерна томографія (КТ) грудної клітки: КТ ознаки тромбоемболії артерій правої легені, правобічна нижньодолева інфаркт-пневмонія, зміни більш характерні для запального процесу в початковій стадії. Ультразвукове дослідження органів черевної порожнини та нирок: дифузні зміни паренхіми печінки, сліди рідини в правій плевральній порожнині.

Висновок. Довготривала іммобілізація у пацієнтів молодого віку може бути єдиним фактором ризику формування тромбоемболії легеневої артерії. 3 метою прогнозування можливих ускладнень у пацієнтів 3 тромбоемболією легеневої артерії в кожному конкретному випадку необхідно враховувати початковий стан пацієнта та супутні захворювання.

КЛЮЧОВІ СЛОВА: тромбоемболія легеневої артерії, молодий вік, ускладнення

\section{ІНФОРМАЦІЯ ПРО АВТОРІВ}

Кульмінська Владислава Юріївна, студентка медичного факультету Харківського національного університету імені В. Н. Каразіна, пл. Свободи, 6, Харків, Україна, 61022, e-mail: kulminskayavl@ gmail.com

ORCID ID: https://orcid.org/0000-0002-5389-2060

Макієнко Наталія Володимирівна, к.мед.н., доцент кафедри внутрішньої медицини, Харківського національного університету імені В.Н. Каразіна, пл. Свободи, 6, Харків, Україна, 61022, e-mail: n.makienko@karazin.ua, ORCID ID: https://orcid.org/0000-0003-2017-350X

Шмидт Олена Юріївна, лікар функціональної діагностики у відділенні функцінальної діагностики ХКЛ УЗ № 1 філії «Центр охорони здоров’я», Акціонерного товариства «Украінська залізниця», асистент кафедри пропедевтики внутрішньої медицини та фізичної реабілітації Харківського національного університету імені В. Н. Каразіна, майдан Свободи, 6, Харків, Україна, 61022, e-mail: shmidt05alena@ gmail.com ORCID - orcid.org/0000-0001-7997-362X 
Івлева Ольга Олексіївна, лікар кардіологічного відділення № 1, ХКЛ УЗ № 1 філії «Центр охорони здоров’я», Акціонерного товариства «Украінська залізниця», Харків, Україна, 61103

\title{
ТРОМБОЭМБОЛИЯ ЛЕГОЧНОЙ АРТЕРИИ В МОЛОДОМ ВОЗРАСТЕ
}

\author{
Кульминская В. Ю., Макиенко Н. В., Шмидт Е. Ю., Ивлева О. А.
}

Вступление. Одним из факторов риска развития тромбоэмболии легочной артерии является возраст \&gt;40 лет. В последнее время встречается все больше случаев развития тромбоэмболии в молодом возрасте, что требует особого внимания в диагностике и лечении.

Цели. Целью данной статьи был анализ клинического случая тромбоэмболии в молодом возрасте.

Материал и методы. Наш пациент Б., 33 года, был неотложно госпитализирован с болью в груди при вдохе, одышкой, кашлем с мокротой с прожилками крови и повышением температуры тела до $37-38,5{ }^{\circ} \mathrm{C} .17 .12 .18$ иммобилизация правой малоберцовой кости. 30.12 .18 г. появилась сжимающая боль в правой половине грудной клетки, одышка, кашель с мокротой с прожилками крови. Была вызвана скорая помощь, но пациент не был госпитализирован. С 31.12.2008 г. по 01.05.2009 г. - температура тела повысилась до $38{ }^{\circ} \mathrm{C} .01 .06 .19$ - рецидив начальных симптомов. 01.07.19 - боль в груди усилилась, пациент был доставлен на машине скорой помощи в больницу. При обследовании: дыхание везикулярное, ослаблено в нижних отделах, преимущественно справа, частота дыхания -20/мин, частота сердечных сокращений 100 уд/мин, артериальное давление 120/70 мм рт. Основной диагноз: тромбоэмболия долевых артерий правого легкого. Класс I, очень низкий риск (43 балла по шкале PESI - индекс тяжести тромбоэмболии легочной артерии, 5 баллов по шкале прогноза Падуи). Осложнение: правосторонняя нижнедолевая инфаркт-пневмония. Сопутствующий диагноз: перелом правой малоберцовой кости. Рекомендуемое лечение: ривароксабан 12 мг; эплеренон 50 мг, цефтриаксон 1 г внутривенно в / в (в / в), левофлоксацин 500 мг в / в, кислородная терапия.

Результаты. Проведены лабораторные и инструментальные исследования. Лабораторные тесты показали увеличение количества лейкоцитов, скорость оседания эритроцитов, АЛТ, тропонина І. ЭКГ: отклонение оси вправо. Компьютерная томография (КТ) грудной клетки: КТ признаки тромбоэмболии артерий правого легкого, правосторонняя нижнедолевая инфаркт-пневмония, изменения более характерны для воспалительного процесса в начальной стадии. Ультразвуковое исследование органов брюшной полости и почек: диффузные изменения паренхимы печени, следы жидкости в правой плевральной полости.

Выводы. Длительная иммобилизация у пациентов молодого возраста может быть только одним фактором риска формирования тромбоэмболии легочной артерии. С целью прогнозирования возможных осложнений у пациентов с тромбоэмболией легочной артерии в каждом конкретном случае необходимо учитывать исходное состояние пациента и сопутствующие заболевания.

КЛЮЧЕВЫЕ СЛОВА: тромбоэмболия легочной артерии, молодой возраст, осложнения

\section{ИНФОРМАЦИЯ ОБ АВТОРАХ}

Кульминская Владислава Юрьевна, студентка медицинского факультета Харьковского национального университета имени В. Н. Каразина, пл. Свободы, 6, Харьков, Украина, 61022, e-mail: kulminskayavl@ gmail.com ORCID ID: https://orcid.org/0000-0002-5389-2060

Макиенко Наталия Владимировна, к.м.н., доцент кафедры внутренней медицины, Харьковского национального университета имени В. Н. Каразина, пл. Свободы, 6, Харьков, Украина, 61022, e-mail: n.makienko@karazin.ua, ORCID ID: https://orcid.org/0000-0003-2017-350X

Шмидт Елена Юрьевна, врач функциональной диагностики в отделении функцінальнои диагностики ХКЛ УЗ № 1 филиала «Центр охраны здоровья», Акционерного общества «Украінська железная», ассистент кафедры пропедевтики внутренней медицины и физической реабилитации Харьковского национального университета имени В. Н. Каразина, пл. Свободы, 6, Харьков, Украина, 61022, e-mail: shmidt05alena@gmail.com ORCID - orcid.org/0000-0001-7997-362X

Ивлева Ольга Алексеевна, врач кардиологического отделения № 1, ХКЛ У3 № 1 филиала «Центр охраны здоровья», Акционерного общества «Українська залізниця», Харьков, Украина, 61103 